\title{
The Power of Representation: Korean Movie Narrators and Authority
}

\author{
Roald Maliangkay
}

In Korea, movie narrators enjoyed the admiration of people across class and cultural differences based on their ability to guide audiences through the many novel, foreign images on screen. But despite the prestige of the narrators' profession, it was a demanding one. They had to deftly maneuver between what would entertain and be appropriate for the people of various social classes and cultural backgrounds, while also complying with the demands of public scrutiny and the many regulations regarding public order. Although it has been suggested that the narrators had some authority on matters related to modernity, it is unlikely that they were ever able to rely on that to escape the reality of the sociopolitical status quo. This article analyzes what factors determined the status of movie narrators in the silent film era. It explores to what extent narrators would have been able to claim authority in the position of both pop star and colonial subject and argues that power effectively relies on the perceived value of the assets one commands.

During the first half of the twentieth century many folk entertainers witnessed the ever increasing competition for work. The many developments in technology introduced during this time, such as photography, radio, and film, created new work opportunities but also significantly changed the settings and conditions of entertainment. One crucial new factor that affected many trades was the development of numerous kinds of marketing tools. Photography arrived in Korea around 1880 and the first shops trading in the technology opened in Korea at the end of the decade. ${ }^{1}$ The reproduction of photographic images did not begin until the mid-1890s, but from the end of the nineteenth century, when the first mov-

Roald Maliangkay is a senior lecturer in Korean studies at the Australian National University. He is particularly interested in the mechanics of cultural policy and the challenges of studying the dynamics of major cultural phenomena. In broad terms, his research analyzes Korea's cultural industries and cultural policy from the early and mid-twentieth century to the present. 
ing images were shown to the public, new printing machines were employed to quickly and accurately reproduce posters, periodicals, and theater or shop leaflets. ${ }^{2}$ By the 1920s, the use of photographic images in advertising would provide considerable support for the stardom of actors and singers and the lure of their appearances. Radio broadcasting began relatively late, in 1927, but it was a comprehensive undertaking that entailed the mobilization of a large number of staff and required, among other things, a network of transmitters and regular programming content. ${ }^{3}$

As entertainment moved inside, the demand for folk performance art that required wide-open stages dwindled, yet for a select few solo performers with the right connections and talents, fame awaited beyond the old confines of local celebrity and word-of-mouth advertising. Sound and image recording and reproduction technology meant that they could become a household name in regions they might never visit, and in homes they would never be invited to. ${ }^{4}$ Although the new media certainly played an important role in the diffusion of Western norms and the standardization of the Korean language across the various regions, a considerable difference between the households remained. Apart from the fact that there continued to be a significant divide between workingclass, middle-class, and upper-middle-class Koreans, ${ }^{5}$ they were joined by a fast growing number of Japanese immigrants, again from various backgrounds, following the Russo-Japanese war (1904-5). ${ }^{6}$ Whereas both class and cultural differences continued to exist in Korea throughout the ensuing decades, the people shared a fascination for the new technologies and the realm of modern pop culture they helped create.

Movie narrators enjoyed the admiration of people across class and cultural differences. They were able to relate to all kinds of audiences regardless of their degree of literacy and to guide them through the many novel and undecipherable images and narratives displayed on screen. On occasion, narrators also introduced new products and technology and performed songs or comic shorts. The popularity of the narrators with Korean and Japanese audiences did not lie merely in their unique skill and understanding of things foreign, but also in the fact that, much like today's TV-show hosts, they were believed to stand at the center of the modern entertainment scene. In their heydays, Korean movie narrators, pyŏnsa (J. benshi), led fairly glamorous public lives, and yet despite the prestige of their profession, it was a demanding one. They had to deftly maneuver between what would entertain, occasionally tantalize, and always be appropriate for the people of various social classes and cultural backgrounds, while complying with the demands of public scrutiny and the increasingly strict and vast regulations regarding public order. Although it has recently been suggested that Korea's first pop stars enjoyed some degree of authority on matters related to modernity, it is unlikely that they were ever able to rely on that authority to escape the reality of the sociopolitical status quo and their position of colonial subject, or move up within the social hierarchy. This article attempts to ascertain 
what factors determined the status of movie narrators in the silent film era. It explores to what extent narrators would have been able to manage power in the position of both pop star and colonial subject and argues that assessments of the narrator's position need to consider the perceived value of their art of narration and the complex relationships narrators had with, among others, the Japanese authorities and the various social classes.

\section{OLD STYLES, NEW TECHNOLOGY}

The majority of large movie theaters were located in Seoul. Since 1876, when Japan forced Korea to sign the Kanghwa Treaty, a fast growing number of Japanese migrated to the peninsula. Around the turn of the century those settling in Seoul accounted for some 20 percent of the total number of Japanese immigrants. At the end of 1904 that number stood at approximately 5,000, but following Japan's victory in the Russo-Japanese war, it began to grow even faster, to 46,067 (18.73 percent of the city's population) in 1910 and 65,617 (26.22 percent) in $1920 .{ }^{8}$ Most of the Japanese expatriates settled just north of Namsan, close to the central railway station where they arrived, as well as in the neighboring areas of Myŏngch'ijŏng (J. Meiji-machi; today's Myŏngdong) and Ponjŏng (J. Hon-machi, today's Ch'ungmuro). It was in these areas that the theaters catering primarily to Japanese clientele were established. Since these neighborhoods comprised the southern part of the old walled city, they were known as "southern town" (namch'on), whereas the shopping and nightlife areas in the more northern parts of Seoul that catered primarily to Koreans, including Chongno and areas to its north, were named the "northern town" (pukch'on).

When the first moving pictures arrived in Korea, they captivated people simply by virtue of the technology. Audiences marveled at the "real" images-the foreign Asian, African-American, and Caucasian faces and previously unseen sights. Around 1897 the most widely available material shown in Korea comprised real-life shorts, "actualités," that entailed mostly scenes of Westerners experimenting with the technology and exploring the wonders of recording movement. In many ways, these films showed that their creators were as captivated by the technology as their audiences. Because until around 1905 these films lasted less than a minute and did not have much narrative, additional information was basic at best. Until film showings became more common, other forms of public entertainment appeared like that of the early forms of film, which closely resembled image card narration. One example was the "Panorama" exhibition, which was held alongside Seoul's central Namdaemun Road from May 13 to June 15, 1897. ${ }^{9}$ It entailed a series of panorama-like photographs of European cities arranged on the inside of a cylindrical wall surrounding the spectator. Presentations of slide photography were a similar and more common form of entertainment. ${ }^{10}$ The format allowed presenters to provide hours of entertainment with 
relatively few slides and, unlike film, at a relatively low cost. Compared to slide lanterns, the predecessor to the slide projector, film projectors were costly, and in the early years it is likely that they were rented as often as bought. There may have been some price competition between the Lumière brothers' Cinématographe and Thomas Edison's Vitascope, but considering the fact that in the 1900s a machine as relatively simple as a record player still cost the equivalent of a laborer's annual salary, ${ }^{11}$ it is unlikely that more than a small number of people or businesses were ever in a position to snap up a "bargain." It is likely, therefore, that only a limited number of private — as opposed to public — film viewings took place around this time.

The length of the film shorts gradually increased, but throughout the first decade of the twentieth century they continued to be little more than snippets. ${ }^{12}$ When eventually, during the first decade of Japanese colonial rule, longer movies appeared, the majority being from North America and Europe, cinemas often split them into two or more parts to ensure that customers came back. Even when one movie was being advertised in particular, most screenings still comprised a selection of shorts. A program leaflet of the Seoul Supreme Entertainment Theater (Kyŏngsŏng Kodŭng Yŏnyegwan) from around 1910 shows that a single program comprised as many as fourteen shorts of various lengths, some rendered in color, some in sepia (yŏmsaek). ${ }^{13}$ They usually entailed simple, real-action scenes from America or Europe, including war footage, ceremonies, or people moving around on various vehicles. ${ }^{14}$ It appears that Koreans quickly grew tired of the lack of a coherent narrative and setting and the lack of sound; like the Japanese, they did not enjoy interpreting the silent snippets on their own accord, but instead preferred to be guided, just like when watching image card or slide shows, even if they could be led in a different direction from that intended by the director of the film.

The first movie narrators emerged around the turn of the century, soon after the first screenings took place. Presumably all amateur enthusiasts at first, a designated person would go up in front of the audience to interpret the silent movements on screen. By the 1910s their role had developed into a profession and although improvements in the quality of the medium never stood still, the narrators continued to play a central role even after the advent of sound technology at the end of the 1920s..$^{15}$ At large theaters, in-house musicians would play an introductory tune at which point the first or main narrator would emerge. Dressed in a suit or frock coat, he would greet the audience before taking his position to the left of the screen. The way in which the narration was presented changed over the years, but it appears that before presenting simultaneous commentary (haesŏl), most narrators provided a lyrical introduction to the program's narrative and foreign content, called chŏnsŏl (chŏn=before/prior, sŏl=explanation). ${ }^{16}$ This prelude covered various aspects including specific locations, occupations, machines, institutions, and even non-verbal communication. The late historian Kim Hwajin recalls a performance by Sŏ Sangho: 
The first movie I saw was Sŏbu hwalgŭk, The Western Plains. It was a scene of a detective pursuing robbers. When a light next to the curtain went on and illuminated the name of Sŏ Sangho, the audience clapped their hands. They cheered. Sŏ Sangho appeared. The car in front is the car of the suspicious-looking guy; the car behind is a police car ...17

The short length of earlier films probably led to the addition of an introduction in order to stretch the duration of the program. As the scope of the narrators' performances increased, so did the amount of attention they drew from the audience.

Music served to push the sound of the projector to the background and helped provide entertainment during unplanned interruptions. The narrator did not always rely on musicians to add sound effects and often added some of his own by, for example, stamping his feet, or beating a small table or drum. The performance setup and the vocal style used for the introduction are clear reminders of the partly sung, partly narrated storytelling tradition that survives in the genre of p'ansori and the folksong piece "Story of Paebaengi" (Paebaengi kut). ${ }^{18}$ Narrators were connected to the musicians and the projectionist by way of a bell cord. By pulling the cord once or twice, a narrator could let his colleagues know that they had to slow down or speed up the film, but there were times when his signals were ignored or misunderstood, so the narrator was forced to adjust his speed himself. Since movie reels were turned by hand, adjusting the speed was easy. The projectionist could, for example, turn the wheel fast in case of an action scene and slow down toward the end of a movie. It is not surprising that when slow motion appeared around 1925, audiences at first thought it was caused by the projectionist. $^{19}$

Unplanned intermissions often happened as a result of films breaking. Because most of the films had been used in Japan for up to three years prior to being imported to Korea ${ }^{20}$ they were often of such poor quality that the audience would have trouble noticing details. Narrators had to be very flexible, therefore, when important sections were particularly unclear, or when it was time to repair or change the film reels. During longer intermissions the narrators made efforts to entertain the audience by loosely talking to them, probably about the film they had just been watching, but because this was not always appreciated I surmise that was why orchestras took over this role from the early $1930 \mathrm{~s}^{21}$

\section{POSITIONS OF POWER}

Throughout the colonial period both Korean and Japanese narrators were employed in Korea. It is not clear what social classes the audiences belonged to at specific cinemas, but we do know that the larger cinemas had rather disparate seating arrangements for three different ticket classes, and that the entertainment venues in the southern town did not, for example, show Korean movies nor 
seek Korean clientele. Dong Hoon Kim suggests ${ }^{22}$ that the ethnic segregation of cinema audiences was complete, but the larger theaters in the northern town certainly welcomed Japanese customers, and they were given a fair amount of attention in a 1936 guide for Japanese tourists. ${ }^{23}$ Until 1912 the Seoul Supreme Entertainment Theater is said to have employed both Japanese and Korean narrators for its ethnically mixed audiences. ${ }^{24}$ Because some Korean narrators were also able to speak Japanese, I surmise that upon the arrival of sound technology the number of Japanese narrators decreased much faster than that of their Korean counterparts. For several years narrators continued to be employed by smaller theaters, in part because the narrators could still rely on their fame and the appeal of their work, but presumably also because the smaller venues took longer to have a sound system installed. ${ }^{25}$ Another reason was that although sound recording technology arrived in the late 1920s, it was limited to diegetic sound at first and thus unsuitable for many action scenes. It was not until "talkies" arrived in the mid-1930s that the work of the narrators began to lose its appeal fast. Unlike in Japan, where groups of four to eight narrators worked together, in Korea narrators usually worked individually, which apart from the fact that the number of Japanese theaters exceeded that of Korean theaters helps to explain why the total number of Japanese narrators active in Korea was much larger. ${ }^{26}$ Although there were a few female narrators among the Japanese narrators active in Korea, the Korean narrators were nearly all male. ${ }^{27}$ Each Korean narrator specialized in a particular genre of films. Since some theaters screened several films consecutively, on rare occasions up to four narrators took turns in providing commentary, but the majority of the theaters could only afford two or three narrators per evening. ${ }^{28}$

During the silent film period, a period with an indefinite ending because of the continued, if marginal, use of narrators until the end of the colonial periodwhereby the sound was simply turned off-many people came to see a specific narrator rather than a specific film, so cinema advertisements sometimes highlighted the narrators performing. Popular narrators were asked to perform live on the radio and on occasion on recordings, either alone, or together with one or two actors. ${ }^{29}$ Their wit, voice, and looks won and broke the hearts of many young women, including young female entertainers (kisaeng). Theaters tried to get the most popular narrators to work exclusively for them offering them competitive salaries, as well as travel expenses and bonuses. As a result, the narrators generally ended up working for only one or two of the major theaters. In the mid1920 s, the heyday of silent films, the average monthly wage of a narrator was 70 to $80 y e n$, with especially popular narrators earning as much as 150 yen, which was almost four times the average wage of rising film stars and high-ranking Korean officials. ${ }^{30}$

It appears that most, albeit not all, narrators had middle-class backgrounds. ${ }^{31}$ Sŏ Sangho (1894-1940), for example, was from Pusan and had learned Japanese from when he was seven or eight years old so he spoke Japanese very well. 
He went to elementary and middle school in Japan, and when he returned to Korea found work first as a policeman and then as an actor. ${ }^{32}$ Another narrator, Kim Tŏkkyŏng, had also finished elementary and middle school and had been employed as a narrator from the age of twenty. ${ }^{33}$ Joe Suh, the grandson of narrator Sŏ Sangp'il's (1901-50) younger brother, told me that Sŏ's father had once been very wealthy, but that he died poor, and that it is likely that Sŏ made his career in movie narration on his own. Whereas his family's fortune may have dried up at some stage, Sŏ still would have had a decent education as well as an important social network to rely on. ${ }^{34}$ The narrators' education and business connections must have allowed them to engage with audiences of different backgrounds and to conduct themselves appropriately in the presence of, for example, Japanese or Korean rich middle classes. Although it is possible that a few narrators climbed up the social ladder through luck and sheer talent, very few theater managers would have given an uneducated laborer the opportunity to present modern technology and to entertain an audience singlehandedly. These narrators may not have been trained in the language of traditional-style narration that narrators commonly used, nor understand modern music and the new products that were shown on screen, but they must have had at the very least connections to the select few who screened films.

Age can play an important role in popular culture stardom, and it certainly would have with narrators. Most of them began at a relatively early age, between the ages of eighteen and twenty-five, and a fair number of narrators continued to work in the profession for more than a decade until the end of the silent film era, which implies that they were at least in their late thirties when they retired from the stage. The Confucian belief that dictates mutual loyalty, including responsibility for those loyal to you (ch'ung), is maintained in South Korea even today, so it is not unlikely that the respect their years of service commanded led theater managers to continue to employ narrators for some time even after the installation of sound film technology. This may have been in part because audiences still enjoyed listening to narrators perform their version of some movies, ${ }^{35}$ but I believe the possibility must be considered that managers' respect for the narrators' years of service constituted a significant factor.

The emerging values of modernity and consumer-capitalism had much persuasive power. Films not only represented the wonders of modernity and the power of capitalism, but they also helped advertise these values on and off the screen. As transmitters of the ideologies, comforts, and values that were part of the newly emerging social order, narrators were in a position of authority. After all, they were allowed to interpret the work of famous Western and Japanese directors on behalf of large audiences. They used their skill to allow audiences to experience developments in modernity on a cultural, political, and technological level using jargon that constituted one of the new-to use Benedict Anderson's words - "languages-of-power" that connected audiences to other modern citizens elsewhere in the world. ${ }^{36}$ Although most movies shown in Korea were of 
foreign origin, a steadily growing number of Korean productions also made it to the screen. Since the Japanese were very much involved in the establishment of the Korean movie industry, the audiences had good reason to question the realism and value of the ideas and representations embedded in Korean productions. The involvement of Korean narrators nevertheless supported the notion of a Korean cinema, despite the fact that they sometimes had to carry out a similar act in front of a Japanese audience, performing the role of both entertainment guide and colonial subject.

Han Sangŏn argues that because of the role they played in people's understanding of cinema, narrators were regarded as intellectuals. ${ }^{37}$ The authoritative power they gained from their role as public interpreter of things foreign was not, however, an established value yet, and may not have been considered important in the eyes of everyone. The term "intellectual" suggests that narrators were in established positions of authority, but as Foucault points out, knowledge and power though certainly related, are always in flux and subjective, and no constant can be given. He points out that power constitutes a series of complex relationships, which cannot be understood based only on analyses of the institutes of power. ${ }^{38}$ In the case of the narrators, one could not ignore, for example, the importance of the colonial subjects' relationship with the state, or with other citizens standing at their respective distance from the vanguard of modernity. The narrators did indeed acquire a measure of authority through their association with modernity, and thus with the classes that managed and created it, but they were not equated with them.

Although knowledge of new developments in key areas implied authority, the values of the many technological changes fell short of representing forms of established knowledge, especially since the style of performance remained very much rooted in tradition. Not until its value was firmly established would the new knowledge truly matter. The work of narrators may have carried some persuasion as a means to acquire or manage power, but because the knowledge they had did not yet represent the power to significantly change their own position within the new status quo, it is unlikely that the majority of their audiences believed the narrators' ideas truly mattered.

Clark W. Sorensen points out that around the turn of the century, when a number of terms were used to denote the common folk, concepts of class were not based on the importance of people's role in business and industry, but rather on the traditional Confucian concept known as "scholar, farmer, craftsman, and merchant" (sa-nong-kong-sang). Modernity and commerce certainly affected these notions of class and they began to be debated from 1910 onwards, if at first mostly by Korean intellectuals. ${ }^{39}$ Farmers, laborers, and those running a simple trade would not have been aware of these discussions, though it is likely that if they deliberated anything sociopolitical, it would have been related to the traditional notions of class. Cinematic presentations of a wide range of foreign cultures would have brought further awareness of the uniqueness of Korean culture, but it now belonged to a Japanese empire that tried hard to erase Koreans' 
traditional notions of class. Some intellectuals were intrigued by the promise of Japan's drive toward modernity, but they were far from a majority. Technological knowhow and understandings of modern - mostly Western - lifestyles and ideas were slowly replacing the value of what was traditionally viewed as important knowledge, ${ }^{40}$ but it is likely that even the Korean and Japanese middle classes were conservative in adopting the new norms, since traditional notions of class remained strong throughout the colonial period, something the narrators would have been very aware of.

\section{EARNING RESPECT AND CERTIFICATION}

Some narrators ended up living an extravagant lifestyle full of alcohol and women. Because their actions were subject to considerable public scrutiny, they sometimes ended up in a scandal. Killick shows that in 1909, on two separate occasions, stones were thrown in protest at the quality of the performances at the Tansŏngsa and Wŏn'gaksa theaters respectively. In April 1913, the Maeil sinbo (Daily Report) reported that So Sangho had sneered at the audience at Umigwan. A year later, narrator Kwŏn Ch'ambong caused another incident when during his stay in P'yŏngyang he fought with a yoggwan manager over the price of the food. ${ }^{41}$ Cho Hŭimun rightly points out that the true details of these incidents will remain obscure, but the fact that they were given so much attention in the media shows that the narrators were being closely followed by the public. ${ }^{42}$ Sŏ Sangho's star antics on stage and ridicule and complaint of Korean people's behavior sometimes earned him and the theater he worked for strong criticism in the media. When on one occasion the aggressive treatment of customers by staff of the Umigwan Theater was made public, the authorities stepped in and forced the theater to submit a letter to the police pledging to prevent any misdemeanor against customers before allowing the theater to continue. ${ }^{43}$ To put on a good face, Umigwan's narrators on one occasion donated money to an orphanage. According to a report in the Maeil sinbo in January 1919, several narrators including one named Iue Ryōkō (井上龍光 Chŏngsang Yonggwang; original name Yi Han'gyŏng) gave money. The public was nevetheless becoming less forgiving and sometimes audiences would still get angry and throw things, such as bits of charcoal. ${ }^{44}$ Despite causing great outrage among their audiences, the theaters continued to rely considerably on the quality and fame of the narrators, which suggests that the attitude of the narrators never had to change much until after the advent of sound film technology. ${ }^{45}$

Brian Yecies and Ae-Gyung Shim note that national film regulations began in August 1918, but other regulations enacted prior to that already affected people's behavior in cinemas. ${ }^{46}$ Killick points out that Japanese claims that Korean theaters went against the Japanese standards of public morality were not unfounded, as they reflected what Koreans themselves had also found, and led to, for exam- 
ple, the closing down of the Hyŏmnyulsa Theater in 1906. He gives examples of reports of the tightening of control of drama performances by the Japanese police in $1909 .{ }^{47}$ When the Japanese annexed Korea in 1910, the police ordered cinemas not to perform plays with any vulgarity nor to open when there were less than forty customers, a measure that saw the number of days that cinemas were open decrease. ${ }^{48}$ In March 1912, the Korean Government-General Ordinance No. 45 (Chosŏn ch'ongdokpu ryŏng) was promulgated, which stipulated, among other things, that any public speech or piece of writing that could incite unrest was forbidden. Until the late 1930s, this ordinance formed the basis for the censoring of public performances. ${ }^{49}$

Following the promulgation of the Public Entertainment Regulation Rules (Hünghaengmul ch'wich'e kyuch'ik) in 1922, a system of official certification was set up, on the basis of which all narrators had to pass an exam in order to acquire the so-called Moving Picture Professional Interpreter License (Hwaltong sajin sŏlmyŏng ŏpcha myŏnhöjŭng). Although it was explained as a licensing regulation, ${ }^{50}$ it effectively put a fair number of narrators out of business. According to Cho Hŭimun, the regulation was meant to limit the impact of the narrators on social morality, even though it merely focused on the language they used, but Sorng Tongho, who took the exam at the time, gives a somewhat different account saying that among the requirements were a proper style of dress and one's refraining from wantonly exciting the audience (kaeksog-ŭl mamdaero tŭnadaekkiji marara) ${ }^{51} \mathrm{He}$ recalled that among the participants there were five narrators from Umigwan Theater, six from Tansongsa Theater, and some fifteen narrators from the countryside..$^{52}$ When the exam was publicly announced a few weeks ahead of the exam, it was said that out of the sixty narrators active in Seoul, twenty-four applied to take the exam; they would be screened based on their conduct and that those who did not meet the requirements would be mercilessly failed (yongsŏ ópsi). The exam was held on June 27, 1922, at the Seoul Police Bureau and lasted until deep into the night. It appears that a much larger number of narrators had come to take the exam, since at the end of the exam, forty-six out of fifty-four candidates passed. According to a report in the Tonga ilbo (East Asia Daily) this group included thirteen Koreans and four (Japanese) women. ${ }^{53}$ Sonng Tongho recalls that it was the job of the narrator to see to it that the audience was shielded from vulgarity:

That was the first time, back then. Around that time for film inspection, an inspector of public order came to the cinema in the day and would inspect a movie showing. What was passable, I don't know, but a kiss was definitely forbidden! Even if the lips would barely touch like this, the scene would be cut. ${ }^{54}$

The Japanese censors scrutinized all aspects of public entertainment, including the advertising and the interpretations of the narrators, but they could never control all connotations and would not have wanted to. As Foucault puts it, "every 
intensification, every extension of power relations to make the insubordinate submit can only result in the limits of power." ${ }^{\prime 5}$ It may have been because they intended to expose the limits of the authorities' control that some narrators took great liberty in explaining a storyline as they risked arrest and torture in order to express their political views. It is reported, for example, that Sin Ch'ul was once arrested and beaten after improvising an anti-Japanese line while narrating a Japanese film in Pusan, while Sŏ Sangp'il famously used the galley slaves' revolt in Ben Hur as a metaphor for the Korean independence struggle. ${ }^{56}$ Interpretations such as these are likely to have been limited to occasions where the audience was predominantly Korean.

The digressions by Korean narrators were similar to those made by their Taiwanese peers, in part because the practice of narration both countries adopted from Japan implied that narrators were expected to go beyond merely translating words and explaining images. Kuei-fen Chiu finds that in Taiwan, local narrators equally challenged the authority of the foreign images in translation thereby contesting the superiority of the colonial ruler with which they were associated. He argues that by taking on the role of narrator Taiwanese were able to "cleverly use the master's tool" to embody the local and subvert the Japanization of colonial subjects. ${ }^{57}$ The argument fails, however, to take into account the complex relationships of power the narrators were subject to. Even when they expressed their support for the cause of the colonized, their audience, and the lower classes in particular, must have realized that by being involved in the novel, popular form of entertainment, the narrators were spokespeople for the new world, and all but underprivileged. Their performance distanced them from the plight of their subjects. ${ }^{58}$ What is more, if one considers Theodor Adorno's concept of pseudo-individualism, then it is likely that the Japanese allowed the occasional expression of social criticism, or at least some public debate about censorship, because it served to create the illusion that the hegemonic reality was a natural one, supported by the majority. ${ }^{59}$ The narrators' digressions ought not, therefore, be interpreted as mere victories, for it was the Japanese authorities after all who created and maintained the status quo in which these victories were reached.

\section{CONCLUSION}

The first movies with sound were those made using the so-called Phonofilm technology created by Lee De Forest. They were rather short and entailed diegetically, "live," recorded sound. They were introduced in Korea in February 1925 at Umigwan Theater and included a violin performance and an American political demonstration on Washington Square. ${ }^{60}$ Yet despite these important new inventions, silent movies continued to be made in Korea. In the late 1920s sound films began to replace silent ones and they slowly and irreversibly transformed the experience of cinema. Yecies points out that academics have adopted too easily 
the year 1935 as the year in which talkies "emerged out of the ethereal." ${ }^{11}$ Despite numerous technological problems, sound eventually turned movies into an experience that allowed Korean audiences to independently interpret the movements on screen, as opposed to one where the interpretation was provided. It did not, however, imply an immediate change from off-screen narration to a diegetic one. Because very few Koreans understood English, let alone the garbled voices of some of the earlier recordings, it was logical that narrators would take over the spoken parts for some time. But the narrators could not hold on to their profession forever, and many of them formed or joined different acts. Those who could not, perhaps because they struggled with the decline in status, found it hard to make a living. This may explain why, in 1940, Sŏ Sangho died from an opium addiction on a corner in Umigwan. ${ }^{62}$

The great fame of some narrators notwithstanding, their work for Korean and Japanese theater managers and audiences implied that at least on stage narrators had to meet their expectations in terms of connotations, humor, and delivery. The language narrators used to deliver their ideas and wit was essential. Unless they were able to communicate with the audience, their art was meaningless. Over the years they may have acquired some respect due to their long service for specific theaters, but that never changed the fact that they had to be effective in delivery. It is likely that they pushed the boundaries of moral acceptance a little, but crossing those boundaries too often could result in the police arresting them or closing their patron theater for a significant number of days, measures they surely would have wanted to avoid. Although narrators played a role in introducing modernity to Korea, Confucian values remained strong among both Koreans and Japanese. The narrators' new status as pop stars would have blurred the traditional notions of class and authority a little, but since all classes could still be distinguished throughout the colonial period, I surmise that despite their fame, knowledge of modernity, and unparalleled income, they would never be mistaken for the elite.

Modernity brought in many new ideals and changes in people's perceptions of class. The changes possibly implied a greater appreciation for Korean pop stars as the holders of new knowledge, but it is likely that people's notions of power changed rather slowly. The value of the traditional forms of knowledge and communication may have begun to fade a little, but most people would still see the status quo as one where besides the colonial government many of the old elite still held on to considerable power, which means that the knowledge they represented continued to maintain its validity. Korean narrators were instrumental in the introduction of the new world, but although they carried a measure of authority on the changes in socio-cultural norms and values, they lacked the social position to make that authority matter. Assessments of the power narrators wielded should thus judge the complexity of their relationships with the various social groups and institutes of power, and it should be conservative, even when considering their heydays. 


\section{NOTES}

1. Until the early 1900s virtually all photography studios in Korea were owned by Japanese businessmen. Yi Kyŏngmin, Kyŏngsŏng, sajin e pakhida, 83, Roald Maliangkay, "New Symbolism and Retail Therapy," 40.

2. Whereas it is unclear when the first moving images were shown in Korea, there is a consensus that it was sometime between 1897 and 1900. Cho Hŭimun, Ch'och'anggi Han'guk yŏnghwasa yŏn'gu, 16-17; Ch'oe Kyujin, Kŭndae rŭl ponŭn ch'ang 20, 199.

3. Michael Robinson, "Broadcasting, Cultural Hegemony, and Colonial Modernity," 54.

4. See Roald Maliangkay, "Their Masters' Voice: Korean Traditional Music SPs (Standard Play Records) under Japanese Colonial Rule,” 55-57.

5. Because of the sociopolitical status quo I eschew categorizing very rich middleclass Koreans as belonging to an upper class. See also Roald Maliangkay, "New Symbolism and Retail Therapy," 30.

6. Yŏ Sŏnjŏng, "Musŏng yŏnghwa sidae singmin toshi Sŏul ŭi yŏnghwa kwallamsŏng yŏn'gu," 12, 14.

7. Han Sangŏn, "Hwaltong sajin sigi Chosŏn yŏnghwa sanŏp yŏn'gu," 99.

8. According to a survey by the Japanese colonial government, the total population of Japanese was 171,543 in 1910, 347,850 in 1920, and 501,867 in 1930. Government-General of Chosen, Thriving Chosen: A Survey of the Twenty-Five Years' Administration, 6.

9. The Independent, May 13, 1897, 4; June 15, 1897, 4.

10. Between December 1899 and October 1901 a few ads for public slide shows appeared in the Hwangsŏng sinmun, December 22, 1899, 2; December 5, 1900, 2; October $25,1901,2$.

11. Although record players went down in price over the years, they were never within easy reach of low-paid workers. See Roald Maliangkay, "Their Masters' Voice," 57, 67.

12. An index of Western moving images from the late 1890s until 1900 reveals that most movies lasted no more than a minute and that only from around 1902 longer movies began to appear that ran for well over half an hour. Robert K. Klepper, Silent Films, 1877-1996, 8-19, 22-40. In the early 1910s even longer movies came to Korea, including Enrico Guazzoni's two hour-long Quo Vadis (1912). Cho Hŭimun, Ch'och'anggi Han'guk yŏnghwasa yŏn'gu, 121.

13. Seoul Museum of History, Kŭndae taejung yesul: Sori wa yŏngsang, 44; see also Cho Hŭimun, Ch'och'anggi Han'guk yŏnghwasa yŏn'gu, 121.

14. Cho Hŭimun, Ch'och'anggi Han'guk yŏnghwasa yŏn'gu, 50, 59, 62, 118.

15. Yŏ Sŏnjŏng, "Musŏng yŏnghwa sidae," 31.

16. This introduction was sometimes preceded by a few words on an upcoming movie. Yi Kyŏngson, "Hwaltong sajin pyŏnsa chwadamhoe," 288-90; Yŏ Sŏnjŏng, "Musŏng yŏnghwa sidae," 31.

17. Kim Yŏngmu, (Musŏng yŏnghwa sijŏl ŭi sŭt'adŭl kwa) Yumyŏng pyŏnsa haesŏl mойтіiр, 12.

18. For more on the element of tradition in the performance of narrators, see Ok Mina, "Pyŏnsa ŭi maegaejŏk wisang mit ŭimi e kwanhan yŏn'gu," 56-57.

19. See also Cho P'ungnyŏn, Sŏul chaphak sajŏn, 185.

20. Brian Yecies and Ae-Gyung Shim, "Lost Memories of Korean Cinema," 81. 
21. Kim Chinsong, Hyŏndaesŏng ŭi hyŏngsŏng, 188.

22. Kim Dong Hoon, "Segregated Cinemas, Intertwined Histories," 17, 22.

23. Yano Hoshino, Shinhan tai Keijō annai, 184-87. Reprinted as Han'guk chiri p'ungsokchi ch'ongsŏ, 448-51.

24. Han Sangŏn, "Hwaltong sajin sigi Chosŏn yŏnghwa sanŏp yŏn'gu," 88, 96.

25. Cho Hŭimun, "Musŏng yŏnghwa ŭi haesŏlcha pyŏnsa yŏn'gu,” 213; Yŏ Sŏnjŏng, "Musŏng yŏnghwa sidae," 18-19.

26. Han Sangŏn, "Hwaltong sajin sigi," 118-19.

27. Cho Hŭimun, "Musŏng yŏnghwa ŭi haesŏlcha pyŏnsa yŏn'gu," 204. There is at least one record of a female Korean narrator by the name of Kang Kyŏngok (康鏡 玉) working at Taejŏnggwan around August 2-17, 1915. See Seoul Museum of History, Kŭndae taejung yesul, 44.

28. Yŏ Sŏnjŏng, "Musŏng yŏnghwa sidae," 33.

29. Ibid., 35.

30. In 1925 this still amounted to no more than half the salary earned by Japanese narrators in Korea. Han Sangŏn, "Hwaltong sajin sigi," 120.

31. Sin Ch'ul (b. 1925) is reported as having been born to a poor family. Walter Lew, "Making Silent Movies Speak," 6-7.

32. Cho Hŭimun, Ch'och'anggi Han'guk yŏnghwa sa yŏn'gu, 129.

33. Maeil sinbo, June 9, 1914, 3.

34. Joe Suh, pers. communication, May 31, 2006.

35. Walter Lew, "Making Silent Movies Speak," 6-7.

36. Benedict Anderson, Imagined Communities, 47.

37. Han Sangŏn, "Hwaltong sajin sigi," 99.

38. Michel Foucault, "Two Lectures," 98; Hubert L. Dreyfus and Paul Rabinow, Michel Foucault: Beyond Structuralism and Hermeneutics, 203, 218, 224.

39. Clark W. Sorensen, "National Identity and the Construction of the Category 'Peasant,", 294-95, 299-300, 304.

40. Yoo Sun-young, "Embodiment of American Modernity in Colonial Korea," 430.

41. Cho transcribes Kwŏn's first name as Sambong. Cho Hŭimun, Ch'och'anggi Han'guk yŏnghwasa yŏn'gu: 109, 130; Maeil sinbo, May 3, 1913, 3; May 28, 1914, 3.

42. Cho Hŭimun, Ch'och'anggi Han'guk yŏnghwasa yŏn'gu, 130-31.

43. Ibid., 109-10.

44. Maeil sinbo, January 16, 1919, 3; January 18, 1919, 3.

45. Andrew P. Killick, "The Invention of Traditional Korean Opera," 81; Cho Hŭimun, Ch'och'anggi Han'guk yŏnghwasa yŏn'gu, 131-32. In 1928 Umigwan was the first theater in Korea to show a sound film. Kim Mihyŏn, Han'guk yŏnghwasa: kaehwagi esŏ kaehwagi kkaji, 27.

46. Brian Yecies and Ae-Gyung Shim, "Lost Memories of Korean Cinema," 78.

47. Andrew P. Killick, "The Invention of Traditional Korean Opera," 84-86.

48. Yi Yongnam, "Haebang chŏn Chosŏn yŏnghwa kŭkchangsa koch'al,” 65.

49. Yu Sŏnyŏng, "Kŭkchang kugyŏng kwa hwaltong sajin pogi," 366.

50. Sŏng Tongho, Yi Kyuhwan, and Ch'oe Kŭmdong, Yi Yŏngil ŭi Han'guk yŏnghwasa rŭl wihan chŭngŏnnok, 25.

51. Cho Hŭimun, Ch'och'anggi Han'guk yŏnghwasa, 125; Sŏng Tongho et al., Yi Yŏngil ŭi Han'guk yŏnghwasa rŭl wihan chŭngŏnnok, 25. 
52. Sŏng Tongho, Yi Kyuhwan, and Ch'oe Kŭmdong, Yi Yŏngil ŭi Han'gukyŏnghwasa rŭl wihan chŭngŏnnok, 24.

53. Tonga ilbo, June 1, 1922; June 28, 1922, 3; Cho Hŭimun, Ch'och'anggi Han'guk yŏnghwasa yŏn'gu: 126. See also Kim Tongho, Han'guk yŏnghwa chŏngch'aeksa, 73, 466; Han Sangŏn, "Hwaltong sajin sigi," 90-91.

54. Sŏng Tongho, Yi Kyuhwan, and Ch’oe Kŭmdong, Yi Yŏngil ŭi Han'gukyŏnghwasa rŭl wihan chŭngŏnnok, 24-27.

55. Hubert L. Dreyfus and Paul Rabinow, Michel Foucault: Beyond Structuralism and Hermeneutics, 225.

56. Walter Lew, "Making Silent Movies Speak," 5; Kenji Ishizaka, Kankoku no sairento eiga to katsudō benshi no sekai, 4.

57. Kuei-fen Chiu, "The Question of Translation in Taiwanese Colonial Cinematic Space," 86,88 .

58. An excellent discussion of how the expression of social critique may "disenfranchise" those seeking to be heard, can be found in Richard Shusterman, ed., Bourdieu: A Critical Reader, 123-25.

59. Theodor W. Adorno, "On Popular Music" (1992), chapter reprinted in John Storey, ed., Cultural Theory and Popular Culture: A Reader, 203-4.

60. Tonga ilbo, October 8, 1927, 3.

61. Brian Yecies, "Sounds of Celluloid Dreams," 166; Kim T'aesu, Kkot kach'i p'iŏ maehokk'e hara, 164.

62. Taehan Min'guk Yesurwŏn [Korean Art Academy], Han'guk yesul sajŏn IV: Han'guk yŏn'gŭk, muyong, yŏnghwa sajŏn, 259.

\section{BIBLIOGRAPHY}

\section{Newspapers}

Hwangsŏng sinmun

The Independent

Maeil sinbo

Tonga ilbo

Adorno, Theodor W. “On Popular Music.” In Cultural Theory and Popular Culture: A Reader, edited by John Storey. Dorchester: Pearson/Prentice Hall, 1998.

Anderson, Benedict. Imagined Communities: Reflections on the Origin and Spread of Nationalism. London: Verso, 2006.

Chiu, Keiu-fen. "The Question of Translation in Taiwanese Colonial Cinematic Space." The Journal of Asian Studies 70, no. 1 (2011): 77-97.

Cho Hŭimun. Ch'och'anggi Han'guk yŏnghwasa yŏn'gu: yŏnghwa ŭi chŏllae wa suyong (1896-1923) [A study of the early period of Korean cinema history: The transmission and reception of movies (1896-1923)]. Ph.D. Diss., Chungang Taehakkyo, 1992.

. "Musŏng yŏnghwa ŭi haesŏlcha pyŏnsa yŏn'gu" [A study of narrators, the interpreters of silent films]. Yŏnghwa yŏn'gu [Film studies] 13 (1997): 182-217. 
Cho P’ungnyŏn. Sŏul chaphak sajŏn [Miscellaneous studies of Seoul]. Sŏul: Chŏngdong ch'ulp'ansa, 1989.

Ch'oe Kyujin. Kündae rŭl ponŭn ch'ang 20 [20 Windows on modernity]. Sŏul: Sŏhaemunjip, 2008.

Dreyfus, Hubert L., and Paul Rabinow. Michel Foucault: Beyond Structuralism and Hermeneutics. Chicago: The University of Chicago Press, 1983.

Foucault, Michel. "Two Lectures." In Power/Knowledge: Selected Interviews and Other Writings 1972-1977, edited by Colin Gordon. New York: Pantheon Books, 1980.

Government-General of Chosen. Thriving Chosen: A Survey of the Twenty-Five Years' Administration. Keijo: Taisho Shashin Kogeisho, 1935.

Han Sangŏn. "Hwaltong sajin sigi Chosŏn yŏnghwa sanŏp yŏn'gu” [A study of the motion picture industry of Korea from 1897 to 1919]. Ph.D. Diss., Hanyang Taehakkyo, 2010.

Kenji Ishizaka. Kankoku no sairento eiga to katsudō benshi no sekai [Korean silent films and the realm of narrators]. Tōkyō: Kokusai Kōryū Kikin Ajia, 1996.

Killick, Andrew P. "The Invention of Traditional Korean Opera and the Problem of the Traditionesque: Ch'anggŭk and its Relation to P'ansori Narratives." Ph.D. Diss., University of Washington, 1998.

Kim Chinsong. Hyŏndaesŏng ŭi hyŏngsŏng: Sŏul e ttansŭ hol ŭl hŏhara [The shaping of modernity: Allow dance halls in Seoul]. Sŏul: Hyŏnsil Munhwa Yŏn'gu, 1999.

Kim, Dong Hoon. "Segregated Cinemas, Intertwined Histories: The Ethnically Segregated Film Cultures in 1920s Korea under Japanese Colonial Rule.” Journal of Japanese and Korean Cinema 1, no. 1 (2009): 7-25.

Kim Mihyŏn. Han'guk yŏnghwasa: kaehwagi esŏ kaehwagi kkaji [A history of Korean movies: From the enlightenment period to the flowering period]. Sŏul: Communication Books, 2006.

Kim T'aesu. Kkot kach 'i p'iŏ maehokk'e hara [Let the flower sprig blossom full of enchantment]. Sŏul: Hwangso chari, 2005.

Kim Tongho. Han'guk yŏnghwa chŏngch'aeksa [A history of Korean film policies]. Sŏul: Nanam Ch'ulp'an, 2005.

Kim Yŏngmu. (Musŏng yŏnghwa sijŏl ŭi sŭt'adŭl kwa) Yumyŏng pyŏnsa haesŏl moümjip [A collection of the interpretations of famous movie narrators (and stars from the silent movie period)]. Sŏul: Ch'angjak Maŭl, 2003.

Klepper, Robert K. Silent Films, 1877-1996: A Critical Guide to 646 Movies. Jefferson, NC: McFarland \& Company Inc., 1999.

Lew, Walter. "Making Silent Movies Speak: Shin Ch'ul's Narration of The Prosecutor and the Lady Teacher." Korean Culture 21, no. 4 (Winter 2000): 4-17.

Maliangkay, Roald. "New Symbolism and Retail Therapy: Advertising Novelties in Korea's Colonial Period.” East Asian History 36 (2008): 29-45.

- "Their Masters' Voice: Korean Traditional Music SPs (Standard Play Records) under Japanese Colonial Rule." The World of Music 49, no. 3 (2007): 53-74.

Ok Mina. "Pyŏnsa ŭi maegaejŏk wisang mit ŭimi e kwanhan yŏn'gu: Han'guk yŏnghwasa esŏ ŭi yŏkhal ŭl chungshim ŭro" [A study of the mediation and meaning of movie narrators: focusing on their role in Korean history]. M.A. thesis, Chungang Taehakkyo, 2003. 
Robinson, Michael. "Broadcasting, Cultural Hegemony, and Colonial Modernity in Korea, 1924-1945. In Colonial Modernity in Korea, edited by Gi-Wook Shin and Michael Robinson. Seattle: University of Washington Press, 1999.

Seoul Museum of History. Kündae taejung yesul: Sori wa yŏngsang [Popular art the modern age: Sounds and images]. Sŏul: Sŏul Yŏksa Pangmulgwan, 2003.

Shusterman, Richard, ed. Bourdieu: A Critical Reader. Oxford: Blackwell Publishers, 1999.

Sŏng Tongho, Yi Kyuhwan, and Ch'oe Kŭmdong. Yi Yŏngil ŭi Han'guk yŏnghwasa rŭl wihan chüngŏnnok [Witness reports for Yi Yŏngil's lectures on Korean cinema history]. Sŏul: Tosŏ ch'ulp'an Sodo, 2006.

Sorensen, Clark W. 'National Identity and the Construction of the Category 'Peasant' in Colonial Korea." In Colonial Modernity in Korea, edited by Michael Robinson and Giwook Shin. Harvard University Press, 1999.

Storey, John. Cultural Theory and Popular Culture: A Reader. Dorchester: Prentice Hall, 1998.

Taehan Min'guk Yesurwŏn [Korean Art Academy]. Han'guk yesul sajŏn IV: Han'guk yŏn'gŭk, muyong, yŏnghwa sajŏn [Dictionary of Korean art: Korean plays, dance and film]. Sŏul: Taehan Min'guk Yesurwŏn, 1985.

Yano Hoshino. Shinhan tai Keijō annai [Survey of Seoul and Inch'ŏn: Revised guide of great Seoul]. Keijō [Seoul]: Keijō toshi bunka kenkyūsho [Research center of the culture of the capital Seoul], 1936. Reprinted as Han'guk chiri p'ungsokchi ch'ongsŏ [A series of records on Korean customs and geography] 35. Sŏul: Kyŏngin Munhwasa, 1989-90.

Yecies, Brian. "Sounds of Celluloid Dreams: Coming of the Talkies to Cinema in Colonial Korea." Korea Journal 48, no. 1 (2007): 160-97.

Yecies, Brian, and Ae-Gyung Shim. "Lost Memories of Korean Cinema: Film Policy during Japanese Colonial Rule, 1919-1937." Asian Cinema, 14, no. 2 (Fall/Winter 2003): 75-90.

Yi Kyŏngmin. Kyŏngsŏng, sajin e pakhida: Sajin ŭro ingnŭn Han'guk kŭndae munhwasa [Seoul, captured in pictures: A cultural history of Korean modernity through photographs]. Sŏul: Sanch'aekcha, 2008.

Yi Kyŏngson. "Hwaltong sajin pyŏnsa chwadamhoe" [Discussion meeting by the narrators of moving images]. Chogwang [Morning light] (April 1938): 288-90.

Yi Yongnam. "Haebang chŏn Chosŏn yŏnghwa kŭkchangsa koch'al" [An examination of the history of Korean cinemas before liberation]. M.A. thesis, Ch'ŏngju Taehakkyo, 2001.

Yŏ Sŏnjŏng. "Musŏng yŏnghwa sidae singmin toshi Sŏul ŭi yŏnghwa kwallamsŏng yŏn'gu" [A study of the film spectatorship in colonial Seoul in the silent film era]. M.A. thesis, Chungang University, 1999.

Yoo, Sun-young (Yu Sŏnyŏng). "Embodiment of American Modernity in Colonial Korea." Inter-Asia Cultural Studies 2, no. 3 (2001): 423-41.

Yu Sŏnyŏng. "Kŭkchang kugyŏng kwa hwaltong sajin pogi: ch'unggyŏk ŭi kŭndae kŭrigo chŭlgŏum ŭi hunyuk" [Looking at theater spectatorship and moving images: the modern age of impact and the conditioning of pleasure]. Yǒksa pip'yŏng [Critical review of history] 64 (2003): 362-76. 